\title{
Selection and Historical Height Data: Evidence from the 1892 Boas Sample of the
}

\section{Cherokee Nation}

\author{
Melinda Miller*
}

U.S. Naval Academy

\begin{abstract}
Economists have increasingly turned to height data to gain insight into a population's standard of living. Because height measures are used when other data is unavailable, testing their reliability can be difficult, and concerns over sample selection have lead to several vigorous debates within the heights literature. In this paper, I use a unique contemporaneous census to gauge the extent of selection into a contested sample of American Indian heights. I have linked people from the 1892 Boas sample of the Cherokee Nation to the 1890 Cherokee Census. An initial analysis finds evidence of negative selection into the Boas sample. A detailed examination of those measured reveals a more complex story. Two distinct groups are present within the data. The first group consists of 64 members of the Cherokee elite. Their households owned more land, had invested more in improvements to their land, and had higher literacy rates. The remainder of the Boas sample is poor relative to both the elite and the rest of the Cherokee Nation. Part, but not all, of this difference is due to their residential location. Forty percent of the Boas sample lived in poorest district of Cherokee Nation. These differences in wealth between the two groups were mirrored by a fairly dramatic difference in average heights. The average height of all men in elite group was $173.9 \mathrm{~cm}$ while the non-elite were several centimeters shorter at just $171.2 \mathrm{~cm}$.
\end{abstract}

\footnotetext{
"Contact: melinda.miller@me.com. Economics Department, USNA, 589 McNair Rd., Annapolis, MD 21402. I thank participants at the 2012 SITE and EHA Annual Meetings for their helpful comments and suggestions. I gratefully acknowledge support of the Yale University Economic Growth Center and the Naval Academy NARC fund. Richard Jantz kindly provided the Cherokee Boas sample.
} 
"Twenty thousand Indians of various types must be measured."

- Franz Boas ${ }^{1}$

\section{Introduction}

In the absence of reliable data on GDP, income or wages, economists have increasingly turned to height data to gain insight into a population's standard of living. ${ }^{2}$ While genetics do influence an individual's stature, final adult height is also determined by net nutrition - diet (calories, nutrition, and protein) less insults to growth (hard work and disease). For a given population, terminal adult heights are normally distributed, and average height reflects the average level of net nutrition during the growing years. By comparing average population heights between societies or across time, economists are able to gain insight into an economy's relative standard of living. (Steckel, 1995)

The very strength of anthropometrics is also its weakness. Because economists tend to rely on height measures when other data is unavailable, this frequently precludes being able to test its reliability. Historical height data is subject to a variety of potential biases, including, "minimum heights standards, age and height heaping, ethnic differences in growth potential, and selectivity of those measured" (Steckel 1995). Econometric techniques can successfully adjust for some of these issues, such as the shortfall that results from the minimum height standards present in some military data (Komlos 2004). However, distributional issues due to sample selection pose a more serious problem. If the criteria for selection into a sample are correlated with height, then

\footnotetext{
${ }^{1}$ Quoted in Starr (1892).

2 See, for example, A'Hearn, 2003; Baten, Ma, Morgan, \& Wang, 2010; Brennan, McDonald, \& Shlomowitz, 1994; Komlos, 2007; Moradi \& Baten, 2005; R. Steckel, 1986; or Stegl \& Baten, 2009. Steckel (2009) found more than 300 social science articles on stature that had been published since 1995 .
} 
the average height of a sample may deviate from that of the population. Simulations have demonstrated that standard statistical tests do not always detect that such selection has occurred (Bodenhorn, Guinnane, and Mroz 2012).

Concerns over sample selections have lead to several controversies within the heights literature, ranging from the impact of industrialization on standards of living (known as the antebellum puzzle) to the growth patterns of slave children. ${ }^{3}$ In this paper, I take advantage of a unique contemporaneous census to evaluate selection into a frequently used and debated sample of American Indian heights. Anthropologist Franz Boas supervised the collection of American Indian physical measurements for an exhibit at the 1893 World's Columbian Exposition. ${ }^{4}$ Because historical economic data on American Indian tribes and nations was sporadic and of questionable reliability, the living standards of American Indians have long been a subject of debate among economists, historians, and policy makers (Snipp, 2004). Steckel and Prince (2001) and Prince and Steckel (2003) utilized the heights collected by Boas to evaluate the standard of living of nomadic American Indians during the mid- to late nineteenth century. Their findings present an optimistic view of living standards, suggesting that Native Americans were successfully able to adapt to a changing environment. Notably, they concluded that

\footnotetext{
${ }^{3}$ Bodenhorn, Guinnane, and Mroz (2014) discuss the potential for sample selection in several of these debates, including military samples, slave heights, and prison records. ${ }^{4}$ Works that have used the Boas sample include, for example, Boas, 1899; Cole, et al., 2008; Gesler, 2008; Jantz, 1995; Jantz, et al., 1992; Jantz, 2003; Konigsberg \& Ousley, 2009; Little, 2010; Moore \& Campbell, 1995; and Szathmáry, 1995.
} 
the equestrian nomads were among the "tallest in the world" and around a full centimeter taller than the second tallest group. ${ }^{5}$

Komlos (2003) and Komlos and Carlson (2014) challenged this interpretation in favor of a more pessimistic view. They asserted that Boas sample suffered from selection. In particular, employees of Indian agencies may have been overrepresented. Because the most educated tribal members tended to hold such jobs, Boas may have included too many members of the tribal upper classes and, hence, a disproportionate number of individuals from the upper tale of the height distribution. Correcting for this shortfall would significantly lower the average height. Komlos and Carlson (2014) also present a contemporaneous sample of U.S. Army Indian Scout heights, which, once adjusted for truncation, were lower and suggested that the, "nutritional status and biological standard of living of Native Americans was on average closer to those of the poorer segments of the U.S. rural population." This analysis cast further doubt on the view that Natives enjoyed high living standards during the nineteenth century.

Like many controversies within the heights literature, evaluating these competing claims can prove difficult. If heights for an entire tribe were known, the population average and distribution could be compared to those of the Boas sample for that tribe. While such a comparison would be ideal, height measurements are not available for an entire tribe. An alternative approach would be to collect detailed economic and demographic information for a tribe. The characteristics of those present in the Boas

\footnotetext{
${ }^{5}$ Steckel (2010) returned to this data when explaining a regional pattern in the average heights of different American Indian tribes. He found that local environmental conditions, particularly biomass and rainfall, influenced final adult heights.
} 
sample could then be compared to the overall population to test for selection on observable demographic and economic characteristics.

I use the latter method to assess the representativeness of the Boas sample by taking advantage of the uniquely well-documented economic history of the Cherokee Nation in Indian Territory. I have located and digitized the entirety of the 1890 Cherokee Nation Census. This census included detailed economic data land use, crop yields, livestock ownership, and capital improvements. Of the 238 Cherokees in the Boas sample, I have linked 80 percent to their information in the 1890 census.

An initial analysis finds no evidence of positive selection into the Boas sample. To the contrary, those in the Boas sample are from households that are, on average, poorer than the overall Cherokee population in 1890 . Their farms are smaller, they own less livestock, they produce fewer crops, and the value of farm improvements lower. These differences are statistically significant. A detailed examination of those measured reveals a more complex story. Two distinct groups are present within the data. The first group consists of 64 members of the Cherokee elite and their families. Among others, the Principle Chief, the Assistant Principle Chief, the editor of the Cherokee Advocate newspaper, senators, and judges were all measured. The members of the elite were wealthier than the overall Cherokee population. Their households, on average, owned more land (87 acres verses 76 acres), had invested more in improvements to their land (\$1237 verses \$977), had higher literacy rates (.90 verses .69) and even owned more clocks ( .8 verses .4$)$. The remainder of the Boas sample is poor relative to both the elite and the rest of the Cherokee Nation. Their household mean land ownership was just 33 acres and the value of improvements only $\$ 570$. 
Part, but not all, of this difference is due to their residential location. Forty percent of the Boas sample lived in the Saline District of the Cherokee Nation. Characterized by a rocky, hilly terrain that was largely unsuited for agriculture, the district was the poorest in the Cherokee Nation. These differences in wealth between the two groups were mirrored by a fairly dramatic difference in average heights. The average height of all males aged 21 years and older in the Cherokee Boas sample was $172.3 \mathrm{~cm}$. The 38 members of the elite meeting these criteria were $173.9 \mathrm{~cm}$ while the 48 non-elite were several centimeters shorter at just $171.2 \mathrm{~cm}$ (p-value of difference 0.02 ).

\section{Boas, Native American Heights, and the Biological Standard of Living}

The debate over the Native American biological standard of living hinges upon the issue of sample selection. Steckel and Prince (2001) were the first economists to apply anthropometrics to the study of Native Americans. Using the Boas sample, they studied the heights of eight Plains Indians tribes. The average height of all adult men in these tribes was $172.6 \mathrm{~cm}$, placing them at the top of the world's height distribution. They were 1 to $2 \mathrm{~cm}$ taller than American soldiers, 3 to $11 \mathrm{~cm}$ taller than Europeans, and slightly taller than Australians. Steckel and Prince attribute this height advantage to a diet rich in protein and nutrients (e.g., buffalo) and a favorable disease environment due to a nomadic lifestyles and low population densities. While acknowledging that the, "details of the sampling procedure... are unknown," they also explicitly counter claims their results were caused due to, "some type of selectivity or sampling bias" by citing contemporaneous accounts that confirm the relatively tall stature of Native Americans. In subsequent works, they affirm the tall heights of Plains Indians and provide additional 
evidence against sample selection. The heights of each tribe are consistent with a normal distribution according to the Shapiro-Wilks test at the 0.10 level (Steckel 2010 and Prince and Steckel 2003).

Komlos and Carlson (2014) disputed that the Boas sample is random and normally distributed and believed it contains too few people to the left of the mean. In contrast to Steckel and Prince, their Shapiro-Wilks test rejects normality for several of the tribes. Furthermore, a histograms of height suggest a short shortfall under $170 \mathrm{~cm}$. They used a truncated regression approach to normalize the sample and estimated the average height as if the full lower tail had been included and found a remarkable consistency across three different samples. The Boas Plains Indians have an estimated height of $170.6 \mathrm{~cm}$, which is $2 \mathrm{~cm}$ shorter than the Prince and Steckel calculations. The entire Boas sample is estimated at $169.6 \mathrm{~cm}$. Results for their new sample of Indian Army Scouts find an average height of $170 \mathrm{~cm}$.

These results suggest that Native Americans were one of the shortest groups in rural America instead of the tallest in the world. Their average height is below samples of U.S. elites, southern white convicts, Union Army soldiers, and Tennessee blacks. They remain, however, quite tall relative to European populations. The descent of Indians to the lower end of the nineteenth century height distribution implies that the their biological standard of living was significantly lower than previously thought, particularly in the years following the American Civil War.

Carlson and Komlos' revision of the average American Indian height rests upon the assumption that there was considerable positive selection into the Boas sample. That is, taller Indians were more likely to be measured. Was there anything in Boas' original 
sampling procedures that could have led to such selection? According to Jantz (1995), Boas' primary goal was to have a large sample - not that the sample necessarily be representative. Boas first conceived collecting the anthropometric data when he was charged with heading the physical anthropology exhibit at the 1893 World's Columbian Exposition in Chicago. In honor of the $400^{\text {th }}$ anniversary of Columbus' discovery of Hispaniola, the Exposition was to feature several displays on America's first inhabitants. The Fair (and its budget) provided Boas with the opportunity to pursue his interest in classifying American Indians into different physical types. Because he was concerned that "full-blood" Indians were rapidly disappearing, Boas decided to particularly focus on "half-breeds" (Boas 1894). To facilitate this wide spread data collection, Boas hired around 50 observers - all were young men and most college students - who were assigned a specific geographic territory. Each measurer was equipped with standardized equipment and Boas himself instructed many in its use.

Once among their assigned tribes, the observers' task was to measure as many people as possible. Boas appealed to the Commissioner of Indian Affairs for assistance, who furnished each observer with a letter of introduction to the local Indian Agent. Some samples reflect the influence of these letters and contain the largely acculturated individuals known to the Indian Agents (Jantz 1995). However, observers also employed a variety of other methods to increase sample size. Starr (1892) described the strategy for measuring the North Carolina Cherokees: "In order to accustom the people to the notion of being measured, it was though wise to deal first with the children in the boardingschool." This strategy also reflects a tendency to focus on locations with a large number 
of potential subjects. Schools and orphanages fulfilled this goal quite well. One observer was sent, for example, to the Carlisle Indian School in Pennsylvania.

Sample composition depended not just on the desires of the observer but also the willingness of Native Americans to be measured. Starr ventured into the community and focused his efforts upon key individuals on whose "consenting to be measured depended much of our success in that whole district." Some people expressed a generalized discomfort with the idea of being measured while others noted physical discomfort. ${ }^{6}$ Some taller people were convinced to be measured by an appeal to tribal pride. Starr warned them that Washington would think their tribe short if the tall men were unwilling to be measured. Women are rare in the sample. Steckel and Prince (2003) attribute this to women's leeriness at being touched by a strange man.

Boas' exhibit became politicized due the actions of a former fair employee. Emma Sickles had been fired after criticizing the Indian exhibits' for, "showing that he [the Indian] is either savage or can be educated only by Government agencies." She then traveled throughout the Indian Territory, giving speeches against the fair and raising interests in alternative Indian exhibits. In an address to the Cherokee National Council, Sickles decried that, "when people come from Europe and all over the world to find the Indian Exhibit they will be taken into a room and shown the measurements of the Indian heads and ears... but I believe that if you should go to the Fair you would want to see something that the Indians can do besides the measurement of Indians heads." She encouraged the Cherokees to attend the fair, demonstrate their skills and level of

\footnotetext{
${ }^{6}$ An elderly woman claimed that the head-measuring calipers were, "worse than being treated for smallpox" (Starr 1892).

${ }^{7}$ Quoted in the New York Times, Oct. 8, 1893.
} 
advancement, and "surprise white people." An editorial in the Indian Chieftain, a newspaper published in the Cherokee Nation, is consistent with Sickles' call: "We must take advantage of this opportunity of showing to the world our advancement in civilization, in arts, and in education."9

While a variety of factors influenced the selection into the Boas sample, the sign of any potential bias is unclear. The presence of acculturated employees of the Indian agency could introduce a disproportionate number of wealthier, taller Indians. Appeals to tribal pride could produce a similar bias. A focus on boarding schools and orphanages would likely target poorer children. Discomfort with being measured has an ambiguous effect. Indians on the lower end of the socioeconomic spectrum may have been more suspicious of the whites, leading to positive selection. However, wealthier tribal members may have felt the measuring process to be demeaning, particularly if they had interactions with Emma Sickles. ${ }^{10}$ Negative selection could then be present.

\section{$3 \quad$ Heights and Census Data in the Cherokee Nation, Indian Territory}

In the summer of 1892, Rupert Henry Baxter, an undergraduate at Bowdoin College, traveled throughout the Indian Territory and Arizona as a Boas observer (Baxter, 1893). One of his stops was the Cherokee Nation; he measured 239 of the Nation's approximately 27,000 citizens. There were nine districts (a county equivalent) within the

\footnotetext{
${ }^{8}$ Her speech was reprinted in the Dec. 7, 1892 edition of the Cherokee Advocate.

${ }^{9}$ Indian Chieftain (Vinita, Cherokee Nation) August 18, 1892.

${ }^{10}$ Sickles continued her involvement in Indian Territory and was met with mixed reactions from some Cherokees. During debates on statehood, the Cherokee Advocate noted that, "She may be perfectly conscientious in her ideas and work in this line, but she may yet live to learn that the Cherokee people are an intelligent, free thinking people, and capable of governing their own affairs." (Cherokee Advocate, May 20,1893).
} 
Nation; Baxter recorded measurements in two. 176 people were measured in the Saline District. Additionally, six children were measured at the Nation's orphan asylum, which was located in Saline. 31 were in the Going Snake district. Map 1 shows the location of these two districts. 26 were measured in other locations or had no recorded location. ${ }^{11}$

Of the 239 measured Cherokees, 182 were males. The 104 men aged 21 years and over had an average height of $172.3 \mathrm{~cm}$. This places the Cherokee men near Prince and Steckel's "tallest in the world" height for Plains Indians and $2 \mathrm{~cm}$ taller than Carlson and Komlos' estimates of Native height. Although shorter than eastern elites $(175 \mathrm{~cm})$, they were taller than members the Ohio National Guard (172.1) and West Point Cadets (171.6), implying that the Cherokees enjoyed a relatively high biological standard of living. ${ }^{12}$ The distribution of Cherokee male heights survives the standard examinations for normality. Figure 1 plots their heights. Although the distribution is somewhat choppy, it roughly follows the overlaid normal curve. The Shapiro-Wilks test fails to reject normality. There is no indication that too few people are in the lower portion of the distribution. 54 people are above the mean, while 50 are below it.

As with most of the Boas sample, women were underrepresented relative to the population. Just 56 were measured. The 34 adults ages 21 and older had an average height of $158.0 \mathrm{~cm}$-approximately the same as free rural black women in Maryland. They are shorter that U.S. elite woman $(163.6 \mathrm{~cm})$, Georgian convicts $(163.4 \mathrm{~cm}$ for white, $161.4 \mathrm{~cm}$ for black), and Plains Indians $(159.1 \mathrm{~cm}$ to $160.6 \mathrm{~cm})$. However, they

\footnotetext{
${ }^{11} 23 \mathrm{had}$ no recorded location. One person was measured in Tishomingo, the capital of the Creek Nation. Another's located was "Uchee Creek, O.T." I have been unable to locate this. Finally, one boy was measured at the Carlisle Indian School.

${ }^{12}$ Comparison heights for men are from Table 1 of Komlos and Carlson (2014).
} 
are tall by European standards $(156.8 \mathrm{~cm}$ for England and 155.4 for Ireland $) .{ }^{13}$ While the Cherokee women appear relatively shorter, one must be cautious not to draw too firm a conclusion from such a small sample. Figure 2 plots the distribution of women's heights. Although rough, there is no indication of positive selection into the sample. There are 18 women below the mean and 16 above. The Shapiro-Wilks test again fails to reject normality.

The sample's average heights are largely consistent with the optimistic view of Native American living standards that Komlos and Carlson (2014) attributed to sample selection. Although the Cherokee sample does not appear on its surface to suffer from shortfall, the inability of standard statistical to detect departures from normality complicate any analysis of this issue. To examine the overall representativeness of the sample, I have linked individuals from the Boas sample to the 1890 Cherokee censuses.

The 1890 Cherokee Census was collected by the Cherokee Nation and enumerated all citizens living in the Nation. I collected full census data for all 26,769 people listed in this census. I then linked people from the Boas sample to their 1890 household on the basis of name and age within 2 years. Of the 239 Boas Cherokees, I found 192 in the 1890 Census for a match rate of 80 percent. Table 1 provides statistics on the linkages. 155 of the 183 men were located. Men were more likely to be linked than women, which was due, in part, to last name changes at marriage and a tendency of Baxter to record a woman's name as "Mrs. Husband's Name." For men, the linked and non-linked samples do not differ significantly based. The average height of the linked and non-linked samples is statistically identical at $172.3 \mathrm{~cm}$ and $172.1 \mathrm{~cm}$. The linked

\footnotetext{
${ }^{13}$ Comparison heights for women are from Table 4 of Komlos and Carlson (2014).
} 
men are 27.5 years on average while the non-linked are 28 years. Women have larger differentials between the linked and non-linked groups. Linked women are 26.8 years old on average, while non-linked women are 4 years older. A height gap also exists between these two groups with linked women around $1.5 \mathrm{~cm}$ shorter. In part due to the small sample size, these differences are not statistically significant.

Table 2 categories reasons for non-successful linkages. There were 24 people whom I could find no reference to in any written Cherokee records. Some may not have been Cherokees but residents of neighboring Indian nations. ${ }^{14}$ Six people had last names that bore no resemblance to known Cherokee names; these names were likely transcribed incorrectly. Three people had either their first or last name missing. There were 4 people who had multiple potential matches. ${ }^{15}$ There were 6 people missing from the 1890 census who appeared in other Cherokee records. Four people in 1890 not linked for other reasons. $^{16}$

\section{Selection and the Cherokee Boas Sample}

To evaluate the likelihood of non-random selection into the Boas sample, I compare household-level economic data for members of the linked Boas sample to a control group of the general population of the Cherokee Nation. Orphans will be omitted from the

\footnotetext{
${ }^{14}$ A family consisting of John Dog, Mrs. John Dog, and two Dog children has a likely match in the Creek Nation, for example.

${ }^{15}$ John Smiths were as ubiquitous in the Cherokee Nation as in the rest of the United States.

16 These include (1) A name and age match who was listed as a "Delaware" and not Cherokee in the census; (2) Mrs. Nicholas Wickliffe, who married between 1890 and 1892, and whose maiden name I have been unable to located; (3) one person whose name is spelled phonetically and has an uncertain match; (4) one person whose name is unique but whose age does not match.
} 
analysis due to their lack of household-level economic information. ${ }^{17}$ Only Cherokee citizens who were racially classified as "Native Cherokees" will be included. Although adopted whites and freedmen were Cherokee by citizenship, Baxter was unlikely to have considered them as eligible for inclusion in Boas' study. I also exclude members of other Indian tribes that had Cherokee citizenship. ${ }^{18} 20,482$ of the Nation's 26,778 enumerated citizens are included in the comparison group. The Boas sample contains 182 people.

Columns 1 through 3 of Table 3 present 1890 summary statistics. People in the Boas group are much more likely to live in the Saline District. While 40 percent of the sample lived in this district, only 6 percent of the comparison group did. They also are more likely to be male and 6.5 years older on average, which reflect that children are underrepresented in the Boas sample relative to the overall population. Some surprising differences emerge between the two groups. Along several measures, Cherokees appear to be negatively selected into the Boas sample. Households in which members of the Boas sample lived had farms that were 24 acres smaller than the Nation's overall average. This difference is significant at the 5\% level. The total value of crops raised was also smaller. After excluding four households that are extreme outliers, the Boas farms crops are worth about half those of the control group. ${ }^{19}$ This difference is significant. Negative selection is also suggested in other measures of wealth and income.

\footnotetext{
${ }^{17}$ Most Boas sample orphans lived in the Cherokee orphan asylum and were enumerated on a special orphan schedule. This schedule was much less detailed that the general population schedule, making it difficult to include the orphans in empirical analysis. ${ }^{18}$ During treaty negotiations following the Civil War, the Cherokee Nation agreed to grant citizenship to a select group of Shawnee and Delaware Indians. They were racially classified as "Adopted Shawnee" and "Adopted Delaware."

${ }^{19}$ Four farms in the Cherokee Nation control group reported incredibly high crop yields. Most notable is the farm of W.H. Shoemake, a district judge, which produced crops valued at over $\$ 948,000$ (1890\$). He reported 92,000 pounds of seed cotton alone.
} 
The Boas households owned less livestock, had fewer valuable improvements on their farms, produced smaller corn and cotton crops, and had fewer newspapers in their residences. Although some of these differences are not significant at traditional levels, they further suggest that the Cherokee Boas sample may have disproportionality drawn from the poorer parts of the Nation. However, the people in the Boas sample do outperform the comparison group with respect to one measure of human capital. While 85 percent of adults in the Boas group were literate, only 69 percent in the comparison group were.

To further explore the correlation between economic status and inclusion in the Boas sample, I regress

(1)

$$
\mathrm{Y}_{\mathrm{i}}=\beta_{0}+\beta_{1} \text { Boas }_{\mathrm{i}}+\gamma \mathrm{X}_{\mathrm{i}}+\varepsilon_{\mathrm{i}}
$$

$\mathrm{Y}_{\mathrm{i}}$ represents an individual's household-level economic status. I use three measures of status - acreage owned, the total value of crops grown and livestock owned, and the total value of physical improvements to property. The latter two are reported in 1890 dollars. Households that owned no acreage, crops, livestock, or improvements are included with a zero value. Boas is an indicator variable equaling one if a person is in the Boas sample, and $\mathrm{X}_{\mathrm{i}}$ is a vector of district-level dummies. Robust standard errors are used. A basic specification without district dummies is reported in columns (1) to (3) of Table 4. All three measures of economic status are negatively correlated with inclusion in the Boas sample. Acreage and total value are statistically significant at the 1 percent level, while the improvements measure is not statistically significant. In the largely agricultural Cherokee Nation, the people measured for Boas' exhibit lived on farms that were 24 acres smaller with fewer improvements than the average Cherokee citizen. These farms, 
perhaps unsurprisingly, produced over $\$ 800$ less value in a given year. In contrast to the Komlos and Carlson critique, Cherokees appear to be negatively selected into the Boas sample.

As discussed above, the Boas sample exhibited another form of selection: location. While 40 percent of those measured lived in the Saline District, only 6 percent of the comparison group did. To examine the connection between residential location and economic status, I next include a series of district-level controls and omit the Saline district. Results are reported in columns (4) to (6) of Table 4. Once the district controls are included, the magnitude of the difference between the Boas sample and the comparison group becomes substantially smaller and insignificant. The difference in acreage, for example, shrinks from 24.56 acres to just .69. Note that the estimated coefficients on all the district indicators are primarily positive and significantly different than the omitted Saline district in all three regressions.

The high proportion of Saline District residents can, in part, explain the negative selection. Columns 4 and 5 of Table 3 reports sample statistics for the Boas and comparisons groups who were residents of the Saline District. The Saline District is economically worse off that the rest of the Cherokee Nation along almost every dimension. On average, households owned smaller farms (34.6 verses 76.5 acres), grew fewer crops (\$57.77 verses $\$ 1091.3)$, owned less livestock (\$486.50 verses $\$ 684.60)$, and had fewer valuable improvements on their property ( $\$ 570.50$ verses $\$ 976.70$ ). They even possessed fewer consumer durables, owning fewer clocks (.28 verses .44$)$ and sewing machines (.25 verses .36) on average. One exception is the number of fruit trees owned, which is higher (although statistically insignificant). The other exception is literacy. 
Around 70 percent of adults in the Saline district and the Cherokee Nation overall are literate. That Saline performs comparably on literacy despite its overall poor economic performance may be due to the Cherokee Nation's long tradition of publicly funded education.

What can explain the economic underperformance of the Saline District? A terrain map of the Cherokee Nation was commissioned by the Department of Interior in 1906. See Map 1. While large portions of the Nation had suitable agricultural land (shaded in yellow), Saline did not and was located in mountainous terrain (shaded in pink). Early settlers of the district were drawn to the natural salt springs for which the district was named. These springs were the primary source of salt in the Nation and surrounding areas until after the Civil War. Laborers, oftentimes slaves, undertook a hot, potentially dangerous brining process to boil off the water and harvest the remaining salt crystals. Technological developments following the Civil War lowered the cost of salt mining in the northern United States, and the old brining facilities in the Cherokee Nation were unable to withstand the loss of slave labor and increased competition (Foreman 1932). The Saline District lost one of its primary industries. With land unsuited to corn or cotton agriculture, its inhabitants focused on livestock and fruit tree production. However, the district was poor relative to the rest of the Nation.

Within the Saline District, the people in the Boas sample appear somewhat better off. There farms are 18 acres larger than average, they own more livestock, and they have planted more fruit trees. They even own, on average, twice as many clocks. These differences are all statistically significant. The Boas sample contains some of the best off of the worst off. A perusal of the names of Boas residents of Saline suggests why this 
may be. Several prominent citizens of the Saline District appear in the Boas sample. They include Bill Smith (elected sheriff in 1891), David Ragsdale (a district judge), Bert Jones (the district's councilor), Thomas Smith (sheriff in 1892), Henry Ross (the district's senator), Nepolean Rowe (elected sheriff in 1893), Frank Conseen (the district's other councilor), Jesse Sunday (sheriff in 1889), and Daniel Redbird (former senator of the district). The most powerful men in the Cherokee Nation also join them in the remainder of the Boas sample. These include C.J. Harris (Principle Chief), Jay Clark (sheriff of Tahlequah), Lacey Hawkins (former senator from Tahlequah), William Eubanks (official translator of the Nation), W.H. Mayes (assistant secretary of the Nation), C.L. Lynch (circuit court judge), and several others.

Emmet Starr's History of the Cherokee and their Legends contains detailed genealogies for many Cherokee families and a complete listing of government officials. Family information is also available in the Dawes Enrollment Interviews. Using information from these sources, I was able to reconstruct social and familial networks among the Boas sample. 66 individuals belong to a fairly tightly knit network of prominent Cherokees. ${ }^{20}$ Many served in the Confederate Army and belonged to the same Masonic Lodge. Figure 3 illustrates the types of connections present within the sample. Those in blue boxes are present in the Boas sample. Those in yellow are not. John Lynch Adair was one of the most prominent and powerful people in the Cherokee Nation and served as the representative to Washington, D.C. Although he was travelling when Baxter visited the Nation, five of his sons (A.F., J.L., Jr., H.M., E.F., and B.M.) were all measured. Hugh M. Adair was the editor the Cherokee Advocate. His name was joined

${ }^{20}$ Two people were part of this network but were not found in the 1890 Census. 
on the masthead by two others, William Eubanks and William Loeser. While William Loeser was not measured, his brother John, with whom he shared a house, was. William Eubanks served as on the Nation's three executive councilors with Daniel Redbird in 1887. Redbird married Sarah, and Joe was their son. In Appendix 1, I provide the names of all the people I have identified as being part of this politically elite network and also describe their interrelationships.

Table 3 reports summary statistics for the elite network and the rest of the Boas sample. The most striking differences within the Boas sample occur between the network of 64 and the rest of the sample. These politically powerful and connected individuals are economically dominant. Their farms are, on average, over 2.5 times as large and grow crops valued proportionally larger. They own twice as much worth of livestock. They grow more corn and cotton. They have own more horses, clocks, and sewing machines. These differences are all statistically significant.

There are, then, two distinct groups within the Cherokee Boas sample-the relatively poor and members of the political elite. To clarify the connections between status, location, and inclusion in the Boas sample, I consider the following regression:

$$
\mathrm{Y}_{\mathrm{i}}=\beta_{0}+\beta_{1} \text { Elite }_{\mathrm{i}}+\beta_{2} \text { Non-Elite }_{\mathrm{i}}+\gamma \mathrm{X}_{\mathrm{i}}+\varepsilon_{\mathrm{i}}
$$

Where $\mathrm{Y}_{\mathrm{i}}$ is again economic status and $\mathrm{X}_{\mathrm{i}}$ is a vector of district-level dummies. I now split the Boas sample into two distinct groups. Elite is an indicator variable that takes a value of 1 for each of the 64 members of the elite network. The remaining 118 members of the Boas sample constitute the non-elite. Robust standard errors are used. Columns 1 through 3 of Table 5 report results of the basic specification. District dummies are included in Columns 4 through 6. 
The estimated coefficient on the non-elite is large and negative in every specification. The non-elite had farms that were estimated to be 44 acres smaller, produce $\$ 776$ less in products, and have physical improvements worth $\$ 400$ less than the comparison group without district controls. These differences were all significant at the 1 percent level. Consistent with the results reported in Table 4, the estimated coefficients decreased in magnitude for each measure of economic status after adding district dummies. However, there continues to be evidence of considerable negative selection. Location alone does not explain the relatively poor economic performance of the nonelites. Their farms are estimated to be 20 acres smaller than those of the comparison group and produced $\$ 292$ less in 1890 . These differences remain significant at the 1 percent level. While the value of improvements coefficient remains negative, it is no longer statistically significant.

In contrast, the estimated coefficients for the elite dummy variable are positive in all regressions. Relative to the control group, the elite of the Boas sample have larger farms with more valuable improvements and higher levels of agricultural production. These differences are not statistically significant in the baseline regressions. However, once the district controls are included, the estimates become statistically significant and much larger in magnitude. This change is, again, partly due to the Saline effect. 28 of the 64 members of the elite live in this district. Once its overall lower average economic performance is taken into account, the elite's economic advantage grows. They owned 40 acres more land, had $\$ 580$ more in agricultural production, and improvements valued at $\$ 480$ higher. 
These differences in wealth between the two groups were mirrored by a dramatic difference in heights. The average height of all males aged 21 years and older in the Cherokee Boas sample was $172.3 \mathrm{~cm}$. The 38 members of the elite meeting these criteria were $173.9 \mathrm{~cm}$ while the 48 non-elite were $2.7 \mathrm{~cm}$ shorter at just $171.2 \mathrm{~cm}$. The p-value of this difference is 0.02. In Figure 4, I plot the kernel densities for all male heights (red), the elite male heights (blue), and the non-elite male heights (yellow). They are roughly normally distributed, with the elite distribution shifted to the right of and the non-elites to left of the overall distribution.

The Cherokee elites are taller than Union Army Soldiers $(173.5 \mathrm{~cm})$, the same height as white Australians $(173.9 \mathrm{~cm})$, and $1.1 \mathrm{~cm}$ shorter than U.S. elite $(175.0 \mathrm{~cm}) .^{21}$ They are also $1.7 \mathrm{~cm}$ taller than the $172.2 \mathrm{~cm}$ attainted by Plains Indians in Steckel and Prince's (2001) analysis of the Boas sample. While the non-elite are tall relative to the European populations, they fall in the middle to lower end of North American heights. They were shorter than Union Army soldiers $(172.2 \mathrm{~cm})$, members of the Ohio National Guard $(172.1 \mathrm{~cm})$ and West Point cadets (171.6). ${ }^{22}$ Even though the non-elite are among the poorer citizens of the Cherokee Nation, they are taller than Komlos and Carlson's (2014) estimate of Indian Scout height of $170 \mathrm{~cm}$.

\section{Conclusion}

The existing debate over the average height of American Indians hinges upon the issue of sample selection. Carlson and Komlos argued that the Boas sample, one of the largest existing samples of Native heights, suffers from positive selection and, therefore,

\footnotetext{
${ }^{21}$ Comparison heights are from Table 1 of Komlos and Carlson (2014).

${ }^{22}$ Comparison heights are from Table 1 of Komlos and Carlson (2014).
} 
overestimates average heights. Prince and Steckel disputed this fact and believe that the tall height of Plains Indians withstands issues of selection. Their debate mirrors a larger one currently occurring over the nature of selection into historical heights sample ((Bodenhorn, Guinnane, and Mroz 2014). I linked one tribe from the Boas sample, the Indian Territory Cherokees, to contemporaneous census data in order to gauge the extent of selection on observables.

There is evidence of differential selection by economics status. Members of the Cherokee elite accounted for 36 percent of the linked Boas sample. The Principal Chief, senators, judges, editors, sheriffs, and the Nation's official translator were all measured for Boas' World's Fair exhibit. This network of elites had higher levels of wealth, as measured by land ownership and improvements, and income, as measured by farm production, than both the remainder of the Boas sample and a comparison group of Cherokee citizens. Their inclusion supports the Carlson and Komlos argument of positive selection. The male elites were $2.7 \mathrm{~cm}$ taller than the non-elite men.

However, the mechanism of selection was more complicated than that proposed by the previous literature. The Cherokees in the Boas sample overall exhibited negative selection - they owned less land and livestock, grew fewer crops, and owned fewer consumer durables. Part of this difference was explained by residential location. Rupert Baxter, the undergraduate from Bowdoin charged with measuring the Cherokees, measured 76 percent of people in the Saline District. This was the poorest part of the Cherokee Nation and the Boas sample contains a disproportionate number of people from the struggling area. While some of the people selected were the elite of district, overall the Saline residents in the Boas sample had lower income and wealth levels than the 
remainder of the sample and the rest of the Cherokee Nation. After controlling for location and elite status, I found that location explained some but not all of the poor economic performance of the non-elite. The Cherokees who resided in areas of the nation besides Saline also were relatively worse off.

What can account for these two forms of selection? The Boas exhibition occurred during politically charged and public debates over the future of American Indians in the United States. The Dawes Act, which had been passed in 1887, began the process of privatizing tribal land. Indian lands and reservations were partitioned into farms and allotted to individual families; remaining land was opened for white settlement. The goal of this process was to encourage assimilation and "civilization." The Cherokee Nation and other tribes in Indian Territory were, due to their lobbying efforts, initially excluded from the Act. There was a vocal contingent of Federal policy makers and reformers who wished to extend allotment to Indian Territory. They couched their motivations in concern over potential land monopolies. Some tribal members, they argued, seized large swaths of land, becoming wealthy and powerful. The rest of their tribes scraped by on tiny landholdings and were enmeshed in poverty. Allotment would allow the Federal government to redistribute tribal land (Harmon 2003).

Baxter visited the Cherokee Nation while these debates were gaining traction. Perhaps expecting a Nation of wealthy elites and an impoverished majority, Baxter found himself measuring wealthy elites and an impoverished majority. The Saline District resembled the picture painted of Indian nations by reformers; it was poor with small farms and a relatively low standard of living. It was not, however, representative of the Cherokee Nation. Members of the Cherokee elite were also aware of these debates and 
frequently emphasized the Cherokee Nation's accomplishments and ability to self-

govern. As both Emma Sickles and editorials in the Cherokee newspapers stressed, the World's Fair exhibit provided an opportunity to demonstrate Cherokee advancement to the world-including their tall statures. The political elite, however, were also not representative of the Nation overall. The Cherokee Boas sample seemingly represents a collision of these two competing views of the American Indian that were being debated within broader policy circles.

\section{Bibliography}

A'Hearn, B. 2003. "Anthropometric Evidence on Living Standards in Northern Italy, 1730-1860." Journal of Economic History. http://www.jstor.org/stable/10.2307/3132440.

Baten, Joerg, Debin Ma, Stephen Morgan, and Qing Wang. 2010. "Evolution of Living Standards and Human Capital in China in the 18-20th Centuries: Evidences from Real Wages, Age-Heaping, and Anthropometrics." Explorations in Economic History 47 (3): 347-59. doi:10.1016/j.eeh.2009.09.003.

Bodenhorn, Howard, Timothy Guinnane, and Thomas Mroz. 2014. "Caveat Lector : Sample Selection in Historical Heights and the." NBER Working Paper.

Bodenhorn, Howard, TW Guinnane, and TA Mroz. 2012. "Sample-Selection Bias in the Historical Heights Literature." http://www.econ.queensu.ca/files/event/GuinnaneOct12.pdf.

Brennan, Lance, John McDonald, and Ralph Shlomowitz. 1994. "Trends in the Economic Well-Being of South Indians under British Rule: The Anthropometric Evidence." Explorations in Economic History 31 (2): 225-60. doi:10.1006/exeh.1994.1010.

Foreman, Grant. 1932. "Salt Works in Early Oklahoma." Chronicles of Oklahoma 10 (4).

Harmon, A. 2003. "American Indians and Land Monopolies in the Gilded Age." The Journal of American History 90 (1): 106-33. http://jah.oxfordjournals.org/content/90/1/106.short. 
Jantz, R L. 1995. "Franz Boas and Native American Biological Variability." Human Biology. http://www.ncbi.nlm.nih.gov/pubmed/7607632.

Komlos, John. 2003. "Access to Food and the Biological Standard of Living : Status of Native Americans Perspectives on the Nutritional." The American Economic Review 93 (1): 252-55.

- - - 2004. "How to (and How Not To) Analyze Deficient Height Samples." Historical Methods: A Journal of Quantitative and Interdisciplinary History 37 (4): 160-73. doi:10.3200/HMTS.37.4.160-173.

- - - 2007. "Anthropometric Evidence on Economic Growth, Biological Well-Being and Regional Convergence in the Habsburg Monarchy, C. 1850-1910." Cliometrica 1 (3): 211-37. doi:10.1007/s11698-007-0013-5.

Komlos, John, and Leonard Carlson. 2012. "The Anthropometric History of Native Americans, C. 1820-1890."

http://papers.ssrn.com/sol3/papers.cfm?abstract_id=2012272.

- - . 2014. "The Anthropometric History of Native Americans, C.1820-1890." In Research in Economic History, Volume 30, edited by Susas Wolcott and Christopher Hanes, 135-61. Emerald Group Publishing. https://books.google.com/books?id=nXUGAwAAQBAJ\&pgis=1.

Moradi, Alexander, and Joerg Baten. 2005. "Inequality in Sub-Saharan Africa: New Data and New Insights from Anthropometric Estimates." World Development 33 (8): 1233-65. doi:10.1016/j.worlddev.2005.04.010.

Prince, JM, and RH Steckel. 2003. "Nutritional Success on the Great Plains : NineteenthCentury Equestrian Nomads." Journal of Interdisciplinary History. http://www.mitpressjournals.org/doi/abs/10.1162/002219502320815163.

Prince, Joseph M, and Richard H. Steckel. n.d. "Net Nutritional Success on the Great Plains: The Remarkable Heights of Equestrian Nomads in the Nineteenth Century."

Starr, Frederick. 1892. "Measuring Cherokees.” The Christian Union 46: 586-88.

Steckel, RH. 1986. “A Peculiar Population, Nutrition, Health and Mortality of Slaves from Childhood to Maturity." Journal of Economic History. http://journals.cambridge.org/production/action/cjoGetFulltext?fulltextid=4145240.

Steckel, RH, and JM Prince. 1998. "Tallest in the World: Native Americans of the Great Plains in the Nineteenth Century." NBER Working Paper. http://www.jstor.org/stable/10.2307/2677910. 
- - . 2001. "Tallest in the World: Native Americans of the Great Plains in the Nineteenth Century.” The American Economic Review 91 (1): 287-94.

http://www.jstor.org/stable/10.2307/2677910.

Steckel, Richard H. 1995. "Stature and the Standard of Living." Journal of Economic Literature 33 (4): 1903-40.

Steckel, Richard H. 2009. "Heights and Human Welfare: Recent Developments and New Directions." Explorations in Economic History 46 (1). Elsevier Inc.: 1-23. doi:10.1016/j.eeh.2008.12.001.

- - . 2010. "Inequality Amidst Nutritional Abundance: Native Americans on the Great Plains." The Journal of Economic History 70 (02): 265-86. doi:10.1017/S0022050710000288.

Stegl, Mojgan, and Joerg Baten. 2009. "Tall and Shrinking Muslims, Short and Growing Europeans: The Long-Run Welfare Development of the Middle East, 1850-1980." Explorations in Economic History 46 (1): 132-48. doi:10.1016/j.eeh.2008.10.003. 
Figure 1: Heights of Cherokee Men, age 21 years and older

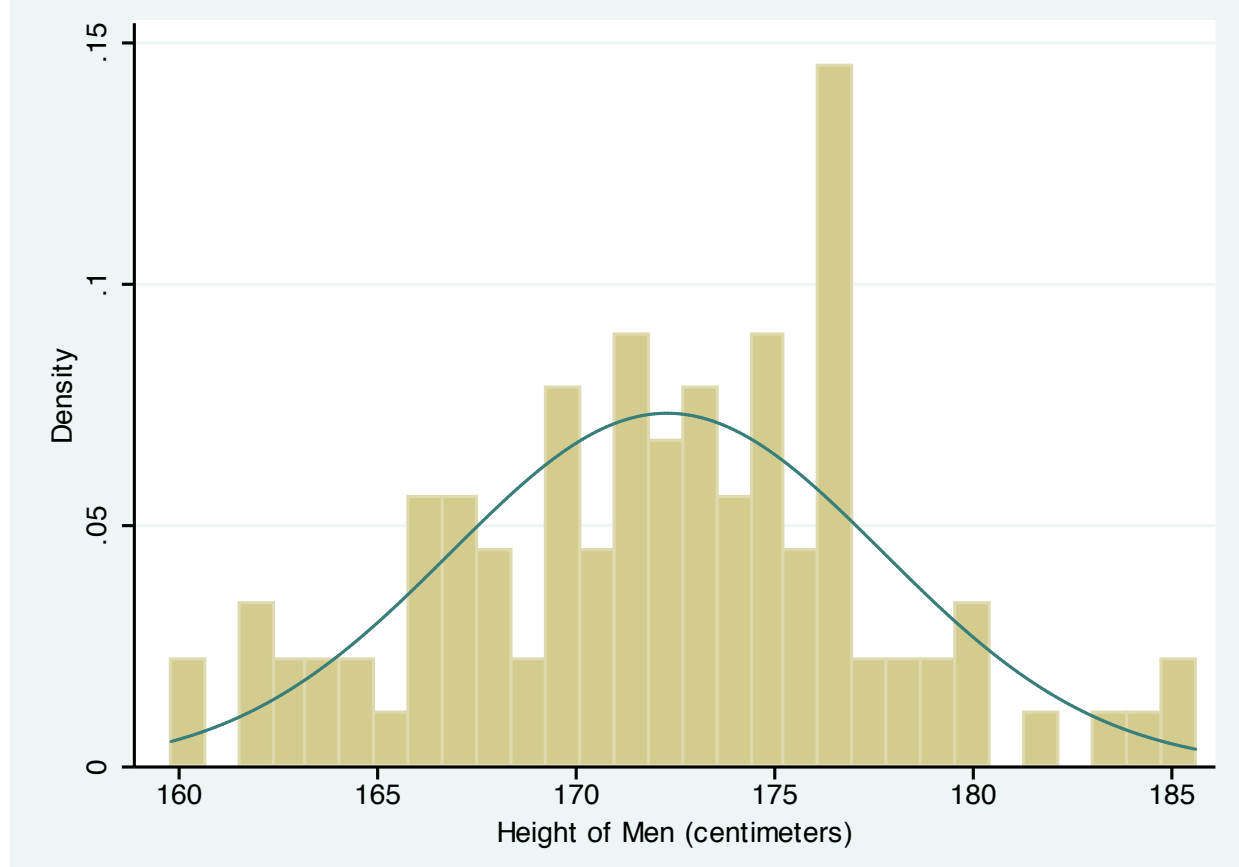

Figure 2: Heights of Cherokee Women, age 21 years and older

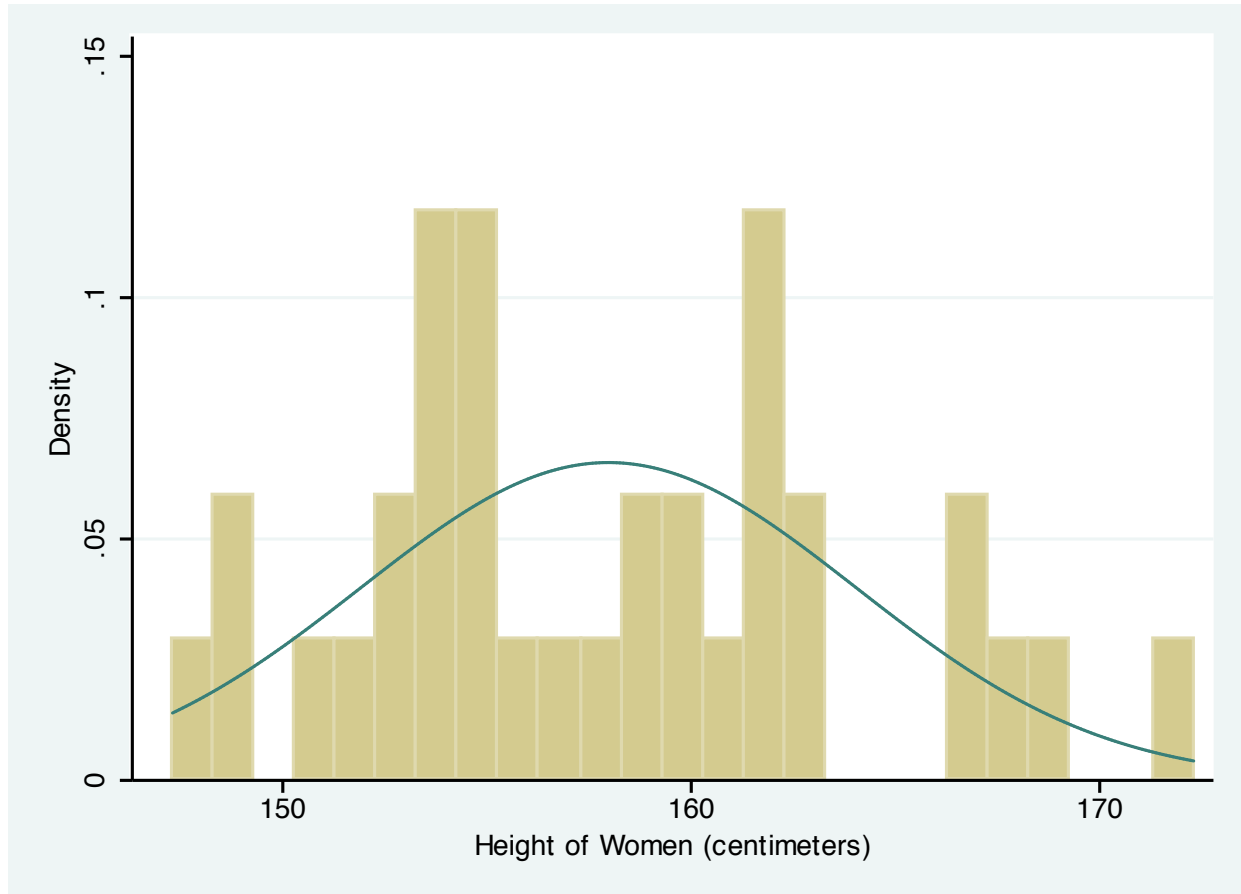




\section{Figure 3: Reconstructed Social Network}

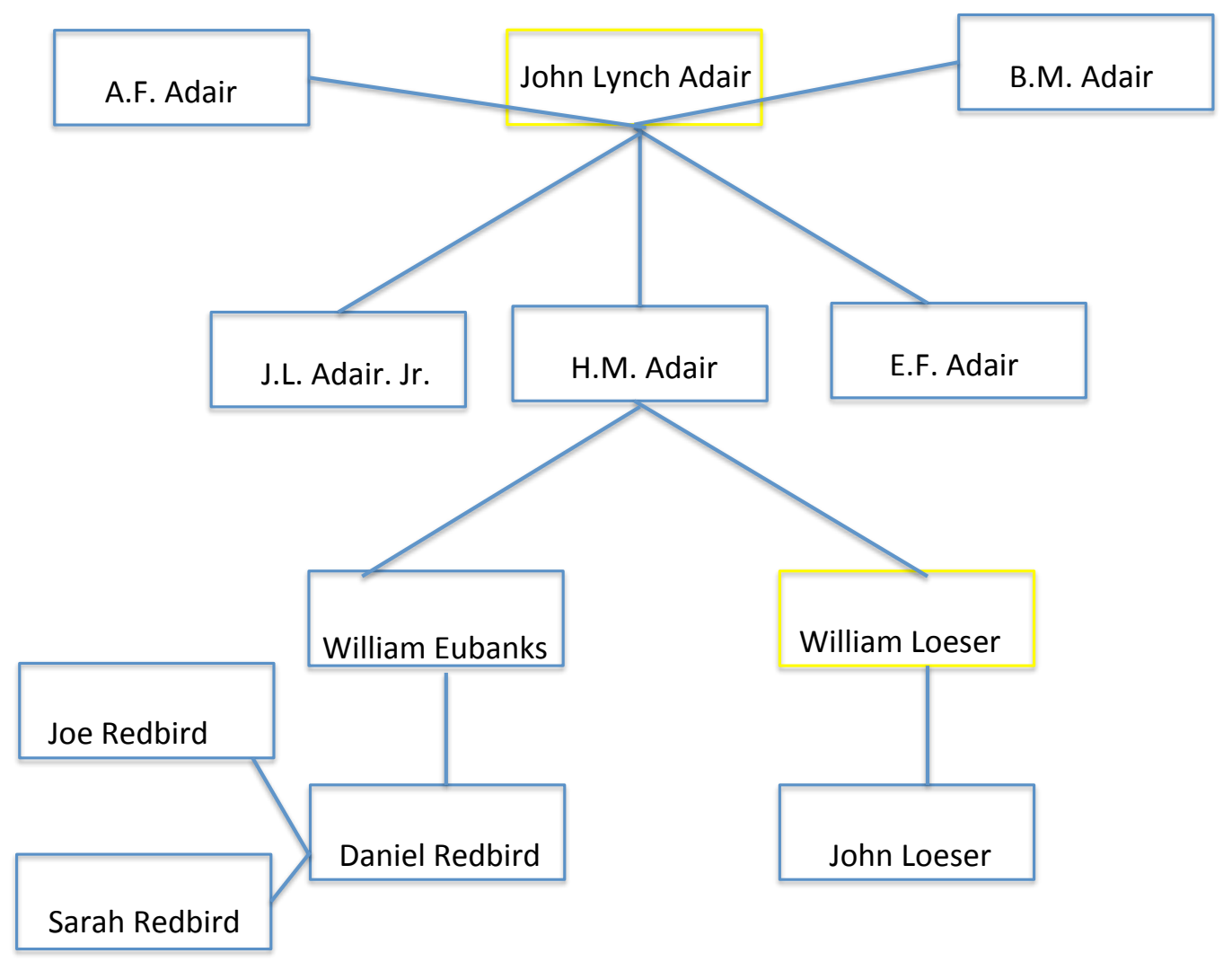


Figure 4: Kernel Densities for Male Heights by Elite Status

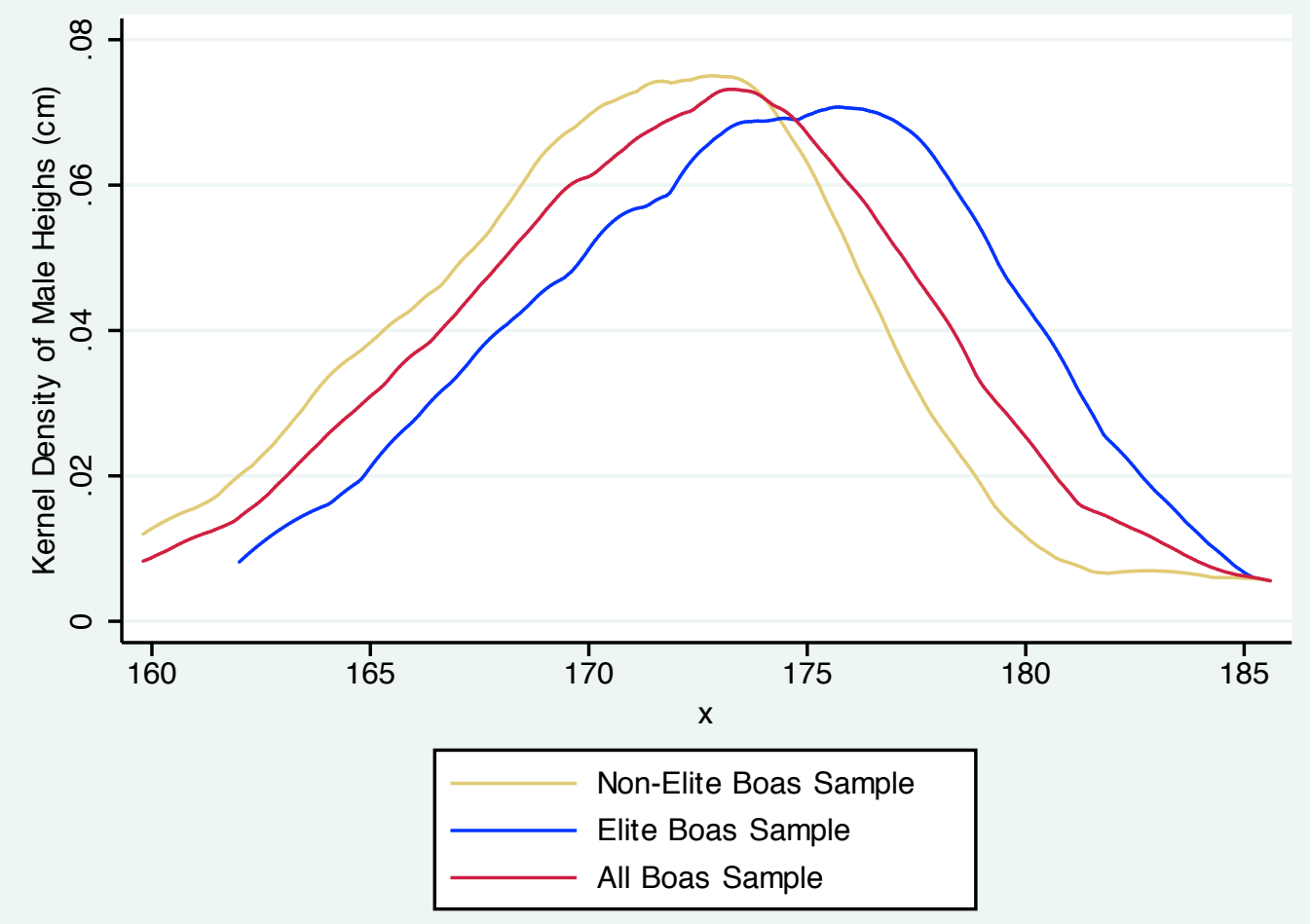




\section{Map 1: Cherokee Nation Districts and Terrain}

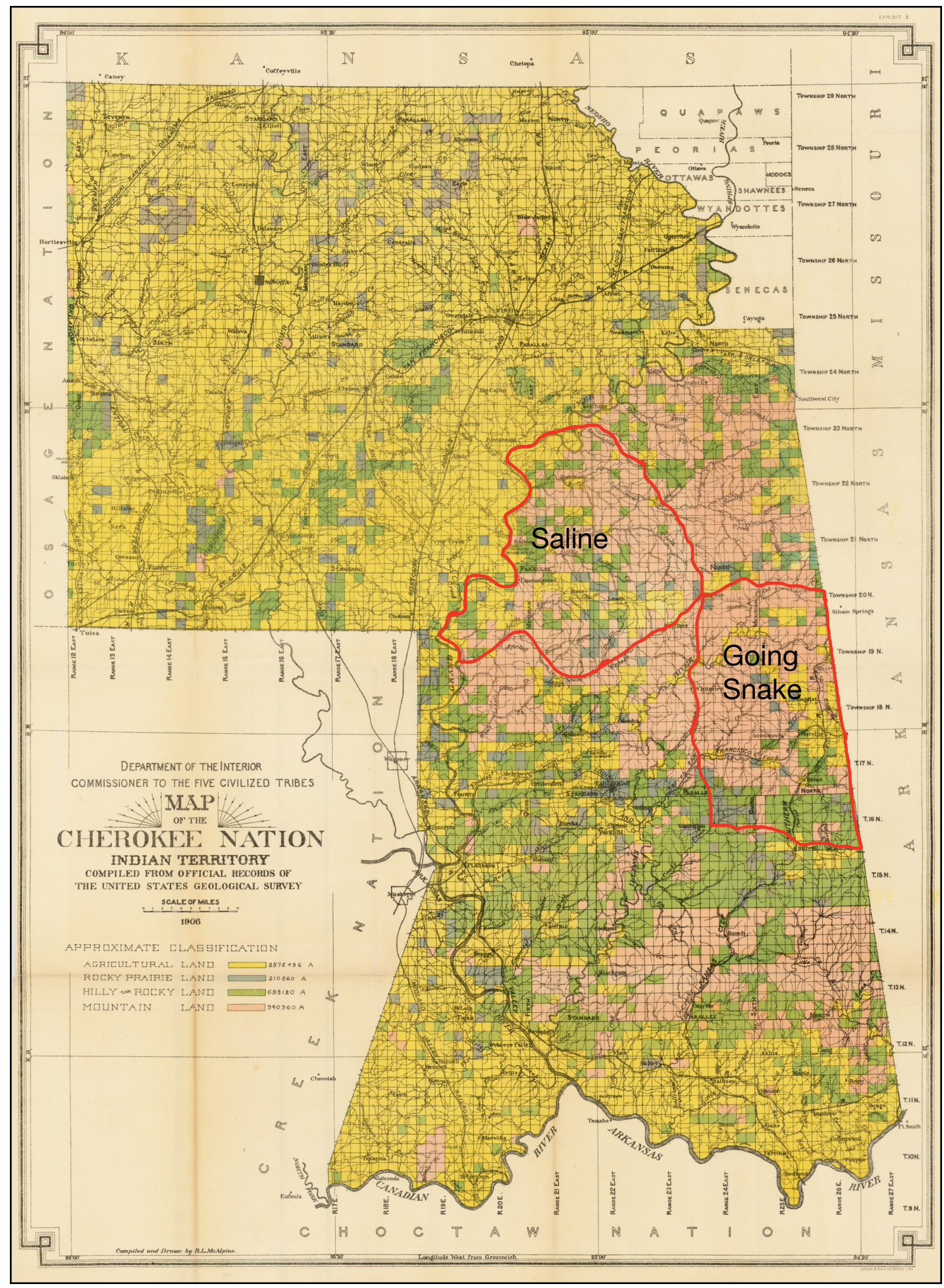

Source: Oklahoma Historical Society 
Table 1: Comparison of Linked and Non-Linked People in Boas Sample

\begin{tabular}{|c|c|c|c|}
\hline & All & Linked & $\begin{array}{c}\text { Non- } \\
\text { Linked }\end{array}$ \\
\hline $\mathbf{N}$ & 239 & 192 & 47 \\
\hline$\%$ Male & 76 & 81.1 & 56.6 \\
\hline Age in Sample & $\begin{array}{r}27.85 \\
{[15.3]}\end{array}$ & $\begin{array}{r}27.5 \\
{[16.1]}\end{array}$ & $\begin{array}{r}29.26 \\
{[13.94]}\end{array}$ \\
\hline \multicolumn{4}{|l|}{ Height } \\
\hline Males 21+ & $\begin{array}{r}172.3 \\
{[5.4]}\end{array}$ & $\begin{array}{r}172.3 \\
{[5.9]}\end{array}$ & $\begin{array}{c}172.1 \\
{[5.8]}\end{array}$ \\
\hline Females 21+ & $\begin{array}{r}158 \\
{[6.3]}\end{array}$ & $\begin{array}{r}157.15 \\
{[6.8]}\end{array}$ & $\begin{array}{r}159.1 \\
{[5.4]}\end{array}$ \\
\hline
\end{tabular}

Source: Author calculations from Boas Sample of Cherokee Nation, Indian Territory. Standard deviations are in brackets.

Table 2: Reasons for Non-Linkage Between Boas Sample and 1890 Cherokee Census

\begin{tabular}{lc}
\hline Reason for Non-Linkage & N \\
\hline No person of name on 1880, & \\
1890, or 1900 Census & 24 \\
Multiple Potential Matches & 4 \\
Not a Last Name & 6 \\
Name all or partially missing & 3 \\
Only in 1880, 1900, and/or & \\
Dawes & 6 \\
Other & 4 \\
\hline Total & 47 \\
\hline
\end{tabular}

Source: Author calculations. 
Table 3: Comparison of Sample Means, 1890 Cherokee Census

\begin{tabular}{|c|c|c|c|c|c|c|c|c|c|}
\hline & 1 & 2 & 3 & 4 & 5 & 6 & 7 & 8 & 9 \\
\hline & $\begin{array}{c}\text { Mean for } \\
\text { Boas } \\
\text { Sample } \\
\text { (Std. Dec.) }\end{array}$ & $\begin{array}{c}\text { Mean for } \\
\text { Comparison } \\
\text { Group } \\
\text { (Std. Dev.) }\end{array}$ & $\begin{array}{c}\text { Difference } \\
\text { (p-value) }\end{array}$ & $\begin{array}{c}\text { Mean for } \\
\text { Boas } \\
\text { Sample, } \\
\text { Saline Only }\end{array}$ & $\begin{array}{c}\text { Mean for } \\
\text { Comparison } \\
\text { Group, } \\
\text { Saline Only }\end{array}$ & $\begin{array}{c}\text { Difference } \\
\text { (p-value) }\end{array}$ & $\begin{array}{c}\text { Mean for } \\
\text { Boas } \\
\text { Sample, } \\
\text { Power } \\
\text { Network }\end{array}$ & $\begin{array}{c}\text { Mean for } \\
\text { Boas } \\
\text { Sample, } \\
\text { Non-Power } \\
\text { Network }\end{array}$ & $\begin{array}{c}\text { Difference } \\
\text { (p-value) }\end{array}$ \\
\hline \multirow{2}{*}{$\begin{array}{l}\% \text { Living in } \\
\text { Saline District }\end{array}$} & 0.396 & 0.0595 & 0.34 & 1 & 1 & & 0.438 & 0.373 & 0.07 \\
\hline & [0.490] & [0.237] & [0.000] & {$[0]$} & {$[0]$} & & {$[0.500]$} & [0.486] & [0.397] \\
\hline \multirow{2}{*}{ Age in 1890} & 25.8 & 19.12 & 6.68 & 25.32 & 21.38 & 3.94 & 29.52 & 23.78 & 5.74 \\
\hline & [15.59] & [16.55] & {$[0.000]$} & [16.62] & {$[17.50]$} & {$[0.063]$} & [18.02] & [13.77] & [0.017] \\
\hline \multirow{2}{*}{ Male } & 0.808 & 0.5 & 0.31 & 0.75 & 0.495 & 0.26 & 0.953 & 0.729 & 0.22 \\
\hline & [0.395] & {$[0.500]$} & {$[0.000]$} & [0.436] & {$[0.500]$} & {$[0.000]$} & {$[0.213]$} & [0.446] & {$[0.000]$} \\
\hline \multirow{2}{*}{$\begin{array}{l}\text { Household } \\
\text { Size }\end{array}$} & 5.346 & 5.606 & -0.26 & 6.167 & 5.192 & 0.98 & 5.938 & 5.025 & 0.91 \\
\hline & [3.383] & [2.818] & [0.272] & [4.059] & [3.809] & [0.035] & [4.646] & [2.405] & [0.082] \\
\hline \multirow{2}{*}{$\begin{array}{l}\text { Farm Size } \\
\text { (Acres) }\end{array}$} & 52.05 & 76.47 & -24.42 & 52.69 & 34.6 & 18.09 & 87.03 & 33.08 & 53.95 \\
\hline & [98.11] & [155.8] & [0.044] & [89.73] & [80.22] & [0.064] & [132.6] & [66.24] & [0.000] \\
\hline
\end{tabular}




\begin{tabular}{|c|c|c|c|c|c|c|c|c|c|}
\hline & 1 & 2 & 3 & 4 & 5 & 6 & 7 & 8 & 9 \\
\hline & $\begin{array}{c}\text { Mean for } \\
\text { Boas } \\
\text { Sample } \\
\text { (Std. Dec.) }\end{array}$ & $\begin{array}{c}\text { Mean for } \\
\text { Comparison } \\
\text { Group } \\
\text { (Std. Dev.) }\end{array}$ & $\begin{array}{c}\text { Difference } \\
\text { (p-value) }\end{array}$ & $\begin{array}{c}\text { Mean for } \\
\text { Boas } \\
\text { Sample, } \\
\text { Saline Only }\end{array}$ & $\begin{array}{c}\text { Mean for } \\
\text { Comparison } \\
\text { Group, } \\
\text { Saline Only }\end{array}$ & $\begin{array}{c}\text { Difference } \\
\text { (p-value) }\end{array}$ & $\begin{array}{l}\text { Mean for } \\
\text { Boas } \\
\text { Sample, } \\
\text { Power } \\
\text { Network } \\
\end{array}$ & $\begin{array}{c}\text { Mean for } \\
\text { Boas } \\
\text { Sample, } \\
\text { Non-Power } \\
\text { Network } \\
\end{array}$ & $\begin{array}{c}\text { Difference } \\
\text { (p-value) }\end{array}$ \\
\hline \multirow{2}{*}{$\begin{array}{l}\text { Total Value of } \\
\text { Crops } \\
\text { Produced } \\
(1890 \$)\end{array}$} & 377.4 & 1091.3 & -713.90 & 56.78 & 57.77 & -0.99 & 633.8 & 238.3 & 395.50 \\
\hline & [1186.2] & [15166.7] & [0.518] & [77.10] & [208.5] & [0.971] & [1780.7] & [643.2] & [0.031] \\
\hline \multirow{2}{*}{$\begin{array}{l}\text { Total Value } \\
\text { of Improve- } \\
\text { ments (1890 \$) }\end{array}$} & 804.5 & 976.7 & -172.20 & 797.4 & 570.5 & 226.90 & 1237.3 & 569.7 & 667.60 \\
\hline & [1472.1] & [2513.0] & [0.383] & [1665.9] & [3038.1] & {$[0.528]$} & [1721.7] & [1264.2] & [0.003] \\
\hline \multirow{2}{*}{$\begin{array}{l}\text { Total Value of } \\
\text { Livestock } \\
\text { Owned (1890 } \\
\text { \$) }\end{array}$} & 588.9 & 684.6 & -95.70 & 767.6 & 486.5 & 281.10 & 867.3 & 437.9 & 429.40 \\
\hline & [851.9] & [3267.5] & [0.734] & [1088.2] & [1014.8] & [0.023] & [945.9] & [758.7] & [0.001] \\
\hline \multirow{2}{*}{ Corn Bushels } & 334.6 & 545.4 & -210.80 & 78.04 & 74.54 & 3.50 & 463.4 & 264.7 & 198.70 \\
\hline & [916.7] & [1352.6] & {$[0.015]$} & [104.5] & [274.7] & {$[0.911]$} & [1039.0] & [839.4] & [0.163] \\
\hline \multirow{3}{*}{$\begin{array}{l}\text { Number of } \\
\text { Fruit Trees }\end{array}$} & 118.9 & 83.56 & 35.34 & 167.9 & 88.24 & 79.66 & 162.1 & 95.47 & 66.63 \\
\hline & [453.9] & [219.4] & [0.026] & [613.4] & [357.7] & [0.081] & [625.9] & [325.9] & [0.345] \\
\hline & 1 & 2 & 3 & 4 & 5 & 6 & 7 & 8 & 9 \\
\hline
\end{tabular}




\begin{tabular}{|c|c|c|c|c|c|c|c|c|c|}
\hline & $\begin{array}{c}\text { Mean for } \\
\text { Boas } \\
\text { Sample } \\
\text { (Std. Dec.) }\end{array}$ & $\begin{array}{c}\text { Mean for } \\
\text { Comparison } \\
\text { Group } \\
\text { (Std. Dev.) }\end{array}$ & $\begin{array}{c}\text { Difference } \\
\text { (p-value) }\end{array}$ & $\begin{array}{c}\text { Mean for } \\
\text { Boas } \\
\text { Sample, } \\
\text { Saline Only }\end{array}$ & $\begin{array}{c}\text { Mean for } \\
\text { Comparison } \\
\text { Group, } \\
\text { Saline Only }\end{array}$ & $\begin{array}{c}\text { Difference } \\
\text { (p-value) }\end{array}$ & $\begin{array}{l}\text { Mean for } \\
\text { Boas } \\
\text { Sample, } \\
\text { Power } \\
\text { Network } \\
\end{array}$ & $\begin{array}{c}\text { Mean for } \\
\text { Boas } \\
\text { Sample, } \\
\text { Non-Power } \\
\text { Network } \\
\end{array}$ & $\begin{array}{l}\text { Difference } \\
\text { (p-value) }\end{array}$ \\
\hline \multirow{2}{*}{ Horses } & 3.797 & 3.851 & -0.05 & 4.958 & 3.13 & 1.83 & 5.031 & 3.127 & 1.90 \\
\hline & [4.564] & [12.82] & [0.987] & {$[5.658]$} & [4.882] & [0.002] & [5.428] & [3.882] & [0.007] \\
\hline \multirow{2}{*}{ Clocks } & 0.538 & 0.437 & 0.10 & 0.528 & 0.284 & 0.24 & 0.797 & 0.398 & 0.40 \\
\hline & {$[0.678]$} & {$[0.582]$} & [0.019] & {$[0.731]$} & [0.611] & [0.001] & {$[0.671]$} & [0.642] & [0.000] \\
\hline \multirow[t]{2}{*}{ Newspapers } & 0.104 & 0.178 & -0.07 & 0 & 0.00412 & 0.00 & 0.141 & 0.0847 & 0.06 \\
\hline & [0.618] & {$[0.830]$} & [0.092] & {$[0]$} & {$[0.0641]$} & [0.586] & [0.687] & {$[0.578]$} & [0.561] \\
\hline \multirow{2}{*}{$\begin{array}{l}\text { Sewing } \\
\text { Machines }\end{array}$} & 0.451 & 0.375 & 0.08 & 0.528 & 0.249 & 0.28 & 0.672 & 0.331 & 0.34 \\
\hline & {$[0.531]$} & [0.509] & [0.034] & {$[0.503]$} & {$[0.448]$} & {$[0.000]$} & {$[0.565]$} & [0.472] & {$[0.000]$} \\
\hline \multirow{2}{*}{ Literate (18+) } & 0.85 & 0.69 & 0.16 & 0.875 & 0.7 & 0.18 & 0.90 & 0.81 & 0.09 \\
\hline & {$[0.361]$} & {$[0.46]$} & {$[0.000]$} & {$[0.335]$} & [0.459] & [0.018] & {$[.297]$} & [.393] & {$[.529]$} \\
\hline \multirow{2}{*}{$\begin{array}{l}\text { No crops, } \\
\text { livestock, or } \\
\text { improvements } \\
\text { recorded }\end{array}$} & 0.09 & 0.15 & & 0.0694 & 0.143 & -0.07 & 0.0781 & 0.10 & \\
\hline & & & & {$[0.256]$} & {$[0.350]$} & [0.225] & {$[.270]$} & [0.304] & [0.523] \\
\hline Observations & 182.00 & 20482.00 & & 72.00 & 1215.00 & & 64.00 & 118.00 & \\
\hline
\end{tabular}


Table 4: Selection into the Boas Sample

\begin{tabular}{|c|c|c|c|c|c|c|}
\hline & 1 & 2 & 3 & 4 & 5 & 6 \\
\hline & Acres & Crop + Stock & Improvements & Acres & Crop + Stock & Improvements \\
\hline \multirow[t]{2}{*}{ Boas $=1$} & $-24.56 * * *$ & $-815.86 * * *$ & -164.59 & 0.69 & -181.16 & 65.1 \\
\hline & [7.399] & [161.700] & [112.443] & [7.588] & [139.069] & [117.661] \\
\hline \multirow[t]{2}{*}{ Delaware } & & & & $117.52 * * *$ & $1,022.94 * * *$ & $758.58 * * *$ \\
\hline & & & & [4.682] & [72.699] & [100.566] \\
\hline \multirow[t]{2}{*}{ Flint } & & & & 1.66 & $388.76^{* * *}$ & $-160.39 *$ \\
\hline & & & & {$[3.105]$} & [100.793] & [83.318] \\
\hline \multirow[t]{2}{*}{ Going Snake } & & & & $9.44^{* * *}$ & $197.76 * * *$ & -41.5 \\
\hline & & & & {$[2.621]$} & [37.485] & [82.999] \\
\hline \multirow[t]{2}{*}{ Illinois } & & & & $10.17 * * *$ & $1,141.50 * * *$ & $355.33 * * *$ \\
\hline & & & & [2.850] & [171.898] & [101.820] \\
\hline \multirow[t]{2}{*}{ Sequoyah } & & & & $53.13 * * *$ & $915.82 * * *$ & $1,395.47 * * *$ \\
\hline & & & & [4.584] & [171.657] & [156.283] \\
\hline \multirow[t]{2}{*}{ Tahlequah } & & & & 3.67 & $417.37 * * *$ & $187.03^{* *}$ \\
\hline & & & & [2.578] & [91.950] & [85.805] \\
\hline \multirow[t]{2}{*}{ Canadian } & & & & $31.87 * * *$ & $5,201.37 * * *$ & $620.33 * * *$ \\
\hline & & & & [3.276] & {$[1,070.617]$} & [99.223] \\
\hline \multirow[t]{2}{*}{ Cooweescoowee } & & & & $91.44 * * *$ & $1,657.81^{* * *}$ & $687.99 * * *$ \\
\hline & & & & [4.404] & [137.617] & [89.326] \\
\hline \multirow[t]{2}{*}{ Constant } & $76.21 * * *$ & $1,769.65^{* * *}$ & $974.47 * * *$ & $34.22 * * *$ & $548.42 * * *$ & $557.43 * * *$ \\
\hline & [1.087] & [109.600] & [17.544] & [2.200] & [32.866] & [81.394] \\
\hline Observations & 20,659 & 20,659 & 20,659 & 20659 & 20659 & 20659 \\
\hline R-squared & 0 & 0 & 0 & 0.08 & 0.01 & 0.03 \\
\hline
\end{tabular}


Table 5: Elite Status and the Boas Sample

\begin{tabular}{|c|c|c|c|c|c|c|}
\hline & 1 & 2 & 3 & 4 & 5 & 6 \\
\hline & Acres & Crop + Stock & Improvements & Acres & Crop + Stock & Improvements \\
\hline \multirow[t]{2}{*}{ Elite } & 11.79 & 95.21 & 266.72 & $39.89^{* *}$ & $579.84 * *$ & $481.92 * *$ \\
\hline & [16.717] & [278.960] & [217.608] & [16.136] & [249.752] & [220.989] \\
\hline \multirow[t]{2}{*}{ Non-Elite } & $-44.44 * * *$ & $-776.09 * * *$ & $-400.74 * * *$ & $-20.69 * * *$ & $-292.77 * * *$ & -162.57 \\
\hline & [6.023] & [97.880] & [119.889] & [6.820] & [109.932] & [126.124] \\
\hline \multirow[t]{2}{*}{ Delaware } & & & & $117.68 * * *$ & $1,035.25 * * *$ & $760.30 * * *$ \\
\hline & & & & [4.680] & [72.604] & [100.599] \\
\hline \multirow[t]{2}{*}{ Flint } & & & & 1.76 & $400.34 * * *$ & $-159.35^{*}$ \\
\hline & & & & [3.103] & [100.710] & [83.337] \\
\hline \multirow[t]{2}{*}{ Going Snake } & & & & $9.70 * * *$ & $210.54 * * *$ & -38.79 \\
\hline & & & & {$[2.622]$} & [37.376] & [83.067] \\
\hline \multirow[t]{2}{*}{ Illinois } & & & & $10.40 * * *$ & $656.87 * * *$ & $358.61 * * *$ \\
\hline & & & & [2.855] & [48.897] & [102.022] \\
\hline \multirow[t]{2}{*}{ Sequoyah } & & & & $53.21 * * *$ & $926.98 * * *$ & $1,396.23 * * *$ \\
\hline & & & & [4.584] & [171.619] & [156.300] \\
\hline \multirow[t]{2}{*}{ Tahlequah } & & & & 3.75 & $238.77 * * *$ & $188.33 * *$ \\
\hline & & & & [2.577] & [39.730] & [85.827] \\
\hline \multirow[t]{2}{*}{ Canadian } & & & & $31.36 * * *$ & $2,382.69 * * *$ & $617.55 * * *$ \\
\hline & & & & [3.273] & [149.556] & [99.358] \\
\hline \multirow[t]{2}{*}{ Cooweescoowee } & & & & $91.55^{* * *}$ & $1,669.24 * * *$ & $689.09 * * *$ \\
\hline & & & & [4.404] & [137.563] & [89.347] \\
\hline \multirow[t]{2}{*}{ Constant } & $76.20 * * *$ & $1,421.49 * * *$ & $974.39 * * *$ & $34.10 * * *$ & $536.15 * * *$ & $556.19 * * *$ \\
\hline & {$[1.088]$} & [32.897] & [17.562] & [2.199] & [32.620] & [81.422] \\
\hline Observations & 20,637 & 20,637 & 20,637 & 20,637 & 20,637 & 20,637 \\
\hline R-squared & 0 & 0 & 0 & 0.08 & 0.02 & 0.03 \\
\hline
\end{tabular}


Appendix 1: Elite in the Boas Sample

\begin{tabular}{|l|l|l|l|}
\hline & Last Name & First Name & Description \\
\hline 1 & ADAIR & H. M. & $\begin{array}{l}\text { 1st Regiment, Cherokee Mounted Volunteers, CSA. Editor, } \\
\text { Cherokee Advocate. }\end{array}$ \\
\hline 2 & ADAIR & JOHN L. Jr. & $\begin{array}{l}\text { Officer in Masonic Lodge. Held positions of Auditor, Clerk of } \\
\text { the Cherokee Senate; Executive councilor under Chief Downing; } \\
\text { Commissioner to re-survey the boundary lines of Cherokee } \\
\text { Nation. Delegate to Washington, D.C. Editor of Cherokee } \\
\text { Advocate. Editor of Indian Chieftain. }\end{array}$ \\
\hline 3 & ADAIR & A. F. & Son of J.L. Adair \\
\hline 4 & ADAIR & T. J. & Son of J.L. Adair \\
\hline 5 & ADAIR & E. F. & Son of J.L. Adair \\
\hline 6 & ADAIR & B. F. & Son of J.L. Adair \\
\hline 7 & BANKS & WILLIAM U. & Translator for Cherokee Advocate (on masthead) \\
\hline 8 & BRYAN & J. M. & $\begin{array}{l}\text { Cousin of Chief J.B. Mayes. Owned store. Father in Cherokee } \\
\text { Mounted Volunteers, CSA, and prominent attorney. }\end{array}$ \\
\hline 9 & BUSHY HEAD & BUTLER & Son of Chief Dennis Bushyhead. \\
\hline 10 & CAREY & MIKE & Wife (Jennie) lived with Arch Spears as child. \\
\hline 11 & CLARK & J. A. & Sherriff of Tahlequah District 1889-1890 \\
\hline 12 & CONSEEN & FRANK & Councilor of Saline District \\
\hline 13 & CONSEEN, Jr. & FRANK & Son of Frank, above. \\
\hline 14 & COVEL & JESSE & $\begin{array}{l}\text { Son of John Henry Covel (district clerk for Delaware and First } \\
\text { Cherokee Mounted Volunteers, CSA). Grandson of Geo Wash } \\
\text { Mayes through mother. }\end{array}$ \\
\hline 15 & DAUNENBURG & R. M. & Father fought for CSA. Enumerator for 1900 U.S. Census. \\
\hline 16 & DOWNING & T. B. & $\begin{array}{l}\text { Undersheriff of GW Mayes. Was elected to the last Cherokee } \\
\text { council. }\end{array}$ \\
\hline & & & \\
\hline
\end{tabular}




\begin{tabular}{|c|c|c|c|}
\hline 17 & EMERSON & TURNER & $\begin{array}{l}\text { Member of Oklahoma Constitutional Convention. Son was MD } \\
\text { and internationally known pathologist and medical author. Father } \\
\text { owned one of the finest farms in Delaware District and fought } \\
\text { with CSA. }\end{array}$ \\
\hline 18 & FIELD & JAMES & Councilor of Delaware District \\
\hline 19 & FIELD & RICHARD & Illinois District representative for the Confederate Convention. \\
\hline 20 & GARRETT & BRUCE & $\begin{array}{l}\text { Father clerk of Going Snake and superintendent of the Male } \\
\text { Seminary in Tahlequah in } 1900 .\end{array}$ \\
\hline 21 & HARRIS & C. J. & Principle Chief \\
\hline 22 & HARRIS & JOHNSON & Son of Chief Harris \\
\hline 23 & HAWKINS & LACEY & $\begin{array}{l}\text { Former senator from Tahlequah. Key figure in Keetoowah } \\
\text { Society. }\end{array}$ \\
\hline 24 & JONES & BERT & Councilor Saline \\
\hline 25 & JONES & JESSE & Son of Bert Joes, above \\
\hline 26 & LEVITT & JOHN & Sherriff of Illinois District \\
\hline 27 & LOESER & JOHN & $\begin{array}{l}\text { Brother was an editor of Cherokee Advocate. John was the } \\
\text { foreman and business manager in } 1890 \text {. On masthead. }\end{array}$ \\
\hline 28 & LYNCH & C.L. & Circuit Court Judge. \\
\hline 29 & MAYES & GEORGE D. W. & $\begin{array}{l}\text { Brother of Chief Samuel Mayes. Father of Sherriff Jesse } \\
\text { Bushyhead Mayes and G.W. Mayes, Councilor from } \\
\text { Cooweescoowee District. }\end{array}$ \\
\hline 30 & MAYES & W. H. & $\begin{array}{l}\text { Brother of both Principle Chief Mayeses. Assistant executive } \\
\text { secretary to Harris. Owned store. 1st Regiment, Cherokee } \\
\text { Mounted Volunteers, CSA }\end{array}$ \\
\hline 31 & McDANIEL & F.M. & Became Deputy Clerk of Claremore and mayor of Bartlesville. \\
\hline 32 & McDANIEL & GEORGE & Brother of F.M. McDaniel, above \\
\hline 33 & MILLS & JAMES LEE & Mayor of Pryor Creek. \\
\hline 34 & NAKEDHEAD & JAMES & Deputy U.S. Marshall, killed by train robbers. \\
\hline 35 & NICKLIFF & JOHN & $\begin{array}{l}\text { Key figure in Keetoowah Society. Chief justice Cherokee } \\
\text { Supreme Court until } 1892 .\end{array}$ \\
\hline
\end{tabular}




\begin{tabular}{|c|c|c|c|}
\hline 36 & NICKLIFF & TOM & Son of John, above. \\
\hline 37 & NICKLIFF, Jr. & JOHN & Son of John, above. \\
\hline 38 & PEAK & S.W. & $\begin{array}{l}\text { Married Charlotte Swimmer, daughter of Wash Swimmer. } \\
\text { Superintendent of schools. Father was deputy sheriff of Illinois } \\
\text { District. }\end{array}$ \\
\hline 39 & RAGSDALE & DAVID & Judge from Saline \\
\hline 40 & REDBIRD & DANIEL & Keetoowah Society key figure. 1891 Senator from Saline. \\
\hline 41 & REDBIRD & $\mathrm{JOE}$ & Son of Daniel, above. \\
\hline$\overline{42}$ & Redbird & Sarah & Wife of Daniel, above. \\
\hline 43 & ROBINSON & EVANS & $\begin{array}{l}\text { Son of Evan Price Robertson, who was a member of the Masonic } \\
\text { Lodge and Reverend. }\end{array}$ \\
\hline 44 & $\mathrm{ROE}$ & POLE & Sherriff of Saline \\
\hline 45 & $\mathrm{ROE}$ & JOE & Son of Pole Roe, above \\
\hline 46 & ROSS & HENRY & $\begin{array}{l}\text { Senator for Saline District. Son of Lewis Ross (John Ross's } \\
\text { brother) }\end{array}$ \\
\hline 47 & ROSS & LONIE & Grandson of Chief John Ross \\
\hline 48 & SAUNDERS & SAGIE & $\begin{array}{l}\text { Popular politician. When the first telephone line was installed in } \\
\text { IT, Soggy was on one end of the line for the first call. }\end{array}$ \\
\hline 49 & SAUNDERS & NELLIE & Wife of Sagie Saunders, above. \\
\hline 50 & SCALES & JOSEPH A. & $\begin{array}{l}\text { 1st Regiment, Cherokee Mounted Volunteers, CSA. Relative of } \\
\text { Chief John Ross. "One of the most brilliant and useful men in the } \\
\text { Cherokee Nation," according to an article in the Chronicles of } \\
\text { Oklahoma. }\end{array}$ \\
\hline 51 & SCRAPPER & GEORGE W. & $\begin{array}{l}\text { Delegate to Washington, D.C. for the Union Cherokees. } \\
\text { Councilman for Goingsnake District for Union Cherokees }\end{array}$ \\
\hline 52 & SMITH & THOMAS & $\begin{array}{l}\text { Sherriff of Saline district. 1st Regiment, Cherokee Mounted } \\
\text { Volunteers, CSA. }\end{array}$ \\
\hline 53 & SMITH & BILL & 1891 sheriff from Saline \\
\hline
\end{tabular}




\begin{tabular}{|l|l|l|l|}
\hline 54 & SPEARS & ARCH & $\begin{array}{l}\text { 1st Regiment, Cherokee Mounted Rifles, CSA. Deputy clerk of } \\
\text { Tahlequah in 1896. U.S. census enumerator in 1900. }\end{array}$ \\
\hline 55 & SUNDAY & JESSE & Sherriff of Saline \\
\hline 56 & SUNDAY & TOM & Brother of Jesse Sunday, above \\
\hline 57 & SUNDAY & JIM & Son of Jesse Sunday, above \\
\hline 58 & SUNDAY & DAVE & Son of Jesse Sunday, above \\
\hline 59 & SUNDAY & ALEX & Son of Jesse Sunday, above \\
\hline 60 & SWIMMER & WASHINGTON & Assistant Chief. Senator. Councilor. \\
\hline 61 & SWIMMER & JOHN & Flint District judge \\
\hline 62 & SWIMMER & CHAROLOTTE & $\begin{array}{l}\text { Daughter of Washington Swimmer, above, and (future) wife of } \\
\text { S.W. Peak }\end{array}$ \\
\hline 63 & THORN & CORNE & $\begin{array}{l}\text { Lived with E.C. Boudinot in 1890. E.C. was prominent Cherokee } \\
\text { and Secretary of Arkansas Secession Committee. }\end{array}$ \\
\hline 64 & TONY & ELI & $\begin{array}{l}\text { Lives with Tom Smith. Father is Levi Tony, 1st Regiment, } \\
\text { Cherokee Mounted Volunteers, CSA. Interpreter for Guion } \\
\text { Miller. }\end{array}$ \\
\hline 65 & TRIPLET & DANIEL & $\begin{array}{l}\text { Son on William Triplet (Cherokee senator from Tahlequah, on } \\
\text { committee to dispose of the Cherokee outlet. 1st Regiment, } \\
\text { Cherokee Mounted Rifles, CSA). Brother of Annie. }\end{array}$ \\
\hline 66 & TRIPLET & ANNIE & $\begin{array}{l}\text { Sister of Daniel Triplet. Daughter of William Triplet (Senator } \\
\text { from Tahlequah and on committee to dispose of the Cherokee } \\
\text { outlet. 1st Regiment, Cherokee Mounted Rifles, CSA) }\end{array}$ \\
\hline
\end{tabular}

